\title{
Inner city air pollution and respiratory health and atopy in children
}

\author{
T. Hirsch*, S.K. Weiland**, E. von Mutius ${ }^{+}$, A.F. Safeca*, H. Gräfe*, E. Csaplovics ${ }^{\S}$, \\ H. Duhme**, U. Keil**, W. Leupold*
}

Inner city air pollution and respiratory health and atopy in children. T. Hirsch, S.K. Weiland, E. von Mutius, A.F. Safeca, H. Gräfe, E. Csaplovics, H. Duhme, U. Keil, W. Leupold. (C) ERS Journals Ltd 1999.

ABSTRACT: The impact of inner city air pollution on the development of respiratory and atopic diseases in childhood is still unclear.

In a cross sectional study in Dresden, Germany, 5,421 children in two age groups (5-7 yrs and 9-11 yrs) were studied according to the International Study of Asthma and Allergies in Childhood (ISAAC) phase II protocol. The prevalences of wheezing and cough as well as doctor diagnosed asthma and bronchitis were assessed by parental questionnaires. Children also underwent skin-prick testing, venipuncture for the measurement of serum immunoglobulin (Ig)E, lung function testing and a bronchial challenge test $(4.5 \%$ saline) to assess airway hyperresponsiveness. Exposure was assessed on an individual basis by relating mean annual air pollution levels $\mathrm{(SO}_{2}, \mathrm{NO}_{2}$, $\mathrm{CO}$, benzene, and $\mathrm{O}_{3}$ ) which had been measured on a $1 \mathrm{~km}^{2}$ grid, to the home and school address of each study subject.

After adjusting for potential confounding factors an increase in the exposure to benzene of $1 \mu \mathrm{g} \cdot \mathrm{m}^{3}$ air was associated with an increased prevalence of morning cough (adjusted odds ratio (aOR)): $1.15 ; 1.04-1.27$ ) and bronchitis (aOR: $1.11 ; 1.03-1.19$ ). Similar associations were observed for $\mathrm{NO}_{2}$ and $\mathrm{CO}$. In turn, the prevalences of atopic sensitization, symptoms of atopic diseases and bronchial hyperresponsiveness were not positively associated with exposure to any of these pollutants.

It is concluded that in this study a moderate increase in exposure to traffic-related air pollution was associated with an increased prevalence of cough and bronchitis, but not with atopic conditions in children.

Eur Respir J 1999; 14: 669-677.
*University Children's Hospital Dresden Germany, ${ }^{* *}$ Institute of Epidemiology and Social Medicine, University of Münster, Germany, ${ }^{+}$University Children's Hospital, Klinikum Innenstadt, Munich, Germany, *Saxony State Agency for Environment and Geology, Radebeul, Germany, ${ }^{\S}$ Institute of Photogrammetry and Remote Sensing, University of Technology, Dresden, Germany.

Correspondence: T. Hirsch, Kinderklinik im Universitäitsklinikum Carl Gustav Carus der Technischen, Universität Dresden, Fetscherstr. 74, D-01307 Dresden, Germany. Fax: 493514585358

Keywords: Air pollution, asthma, atopy, bronchial hyperresponsiveness, children, traffic

Received: September 181998

Accepted after revision June 71999

This study was funded by the European Union project "Phare" immission monitoring programme; and the German Ministry of Education, Science, Research and Technology cross sectional study.
The potential health effects of long-term exposure to outdoor air pollution on the respiratory tract of children has been the focus of much research in recent years. Several authors reported a significant association between increased exposure to particulate matter [1-4], $\mathrm{SO}_{2}[1,3,4]$, $\mathrm{O}_{3}[5]$ and nitrogen oxides $[3,4,6]$ and the occurrence of respiratory tract illnesses. Not all reports attempted to discriminate between the different phenotypes of these conditions. Reports that provide detailed information suggest an effect on the prevalence of cough and bronchitis, but not on asthma and atopy [2, 7, 8].

Other epidemiological studies found an association between automobile $[9,10]$ or truck traffic frequency [1113] and wheeze. Higher exposure to truck traffic and black smoke was also associated with impaired forced expiratory volume in one second (FEV1) [14]. Some studies also reported an association between truck traffic frequency $[12,13]$ or black smoke exposure $[11]$ and symptoms of allergic rhinitis. A large Italian study on 39,275 children [15] found a significant association between truck traffic exposure and wheeze, but the associations with other respiratory symptoms (cough and phlegm) were more pronounced. No positive associations were seen between traffic exposure and doctor-diagnosed asthma [9, 11], atopy [11] or bronchial hyperrespon-siveness (BHR) [9]. In contrast to these findings data from in vitro studies and laboratory experiments suggest that particles from diesel exhaust, one of the major contributors to particulate matter pollution in urban areas, specifically promote allergic reactions and BHR [16].

Limitations of study design and exposure assessment have hampered the interpretation of published epidemiological findings. Exposure to air pollution was often assessed through only one or a few monitoring stations supposed to represent air pollution levels over a large area. However, concentrations of certain pollutants such as $\mathrm{NO}_{2}$ have been shown to vary substantially over short distances [17]. Surveys comparing prevalences of disease between regions with different air pollution concentrations are prone to confounding by factors characteristic of the respective study area such as meteorological or socioeconomic conditions. Finally, studies focusing on traffic frequency as a global estimate of vehicle exhaust exposure do not take into account other potential sources of inner city air pollution.

The aim of this study was to relate the prevalence of respiratory and allergic diseases in childhood to measurements of outdoor air pollutant concentrations in the city of 
Dresden, Germany. To distinguish asthma from other respiratory conditions objective measures of parameters closely associated with asthma such as BHR and atopic sensitization were analysed. The individual exposure to outdoor air pollutants was estimated using detailed measurements of annual mean concentrations of $\mathrm{SO}_{2}, \mathrm{NO}_{2}, \mathrm{CO}$, benzene, and $\mathrm{O}_{3}$ for a $1 \mathrm{~km}^{2}$ grid in the city of Dresden.

\section{Methods}

\section{Study population and health outcome measurements}

Dresden, a city with 480,000 inhabitants and an area of $226 \mathrm{~km}^{2}$, is located in the south-east of Germany. Between September 1995 and June 1996 all children participating in the school entry examinations $(n=3,866)$ and a random sample of school children attending fourth grade classes $(n=3,668)$ were studied using the Phase II modules of the International Study of Asthma and Allergies in Childhood (ISAAC) [18]. Because all school beginners were 5-7 yrs of age at the time of investigation, and most fourth grade pupils were 9-11 yrs old (98.8\%) the authors will refer in the following text to 5-7 and 9-11 yr old children, respectively.

Parental questionnaires were distributed through the community health department which conducts the school entry examinations for 5-7 yr olds and through the schools for 9-11 yr olds. A completed questionnaire was returned by parents of 3,312 (83\%) children of ages 5-7 yrs and of $3,045(85.7 \%)$ children of ages $9-11$ yrs. The questions on respiratory and allergic disorders included those developed for the ISAAC-project [19]. The focus of this analysis is on responses to the ISAAC questions on "wheeze in the last 12 months", "number of wheezing attacks in the last 12 months", and on "sleep-disturbing" and "speech-limiting" wheezing in the last 12 months. Symptoms of allergic rhinoconjunctivitis ("sneezing or runny, or blocked nose without a cold" and "itchy-watery eyes") and atopic eczema ("itchy-rash") during the last year were also assessed via ISAAC core questions.

In addition, a question on morning cough as a symptom of nonspecific airway irritation was asked ("Did your child frequently cough in the morning right after waking up in the last 12 months?"). This question had been developed for questionnaires of the British Medical Research Council [20]. Parents were furthermore asked: "Did a doctor ever diagnose any of the following diseases in your child? a) asthma; b) asthmatic, spastic or obstructive bronchitis; c) bronchitis. Children were defined as having asthma, if a doctor had diagnosed "asthma" at least once or "asthmatic, spastic or obstructive bronchitis" more than once. Children were classified as having bronchitis, if a doctor had diagnosed "bronchitis" more than once, and if these children did not meet the definition criteria for asthma. The questions on doctor's diagnoses of asthma and bronchitis included in this study were validated against BHR to cold air in Bavarian schoolchildren [21]. Finally, questions on living conditions, family background and traffic density on the street of residence were evaluated.

All 9-11 yr olds and a random subsample of 5-7 yr olds $(n=2,328)$ were invited to take part in skin-prick tests (SPT) and blood sampling (ISAAC Phase II modules). The SPTs were performed on the left forearm using ALK lancets and standardized allergen extracts of mixed grass pollen, mixed tree pollen, Alternaria tenuis, Dermatophagoides pteronyssinus and D. farinae, and cat (ALK laboratories, Hörsholm, Denmark). The wheal size was calculated as the mean of the long axis and its perpendicular. Atopic sensitization was defined as a wheal of $\geq 3 \mathrm{~mm}$ to at least one allergen after subtraction of the reaction to the negative control. SPT results of children reacting negative to histamine (wheal $<2 \mathrm{~mm}, \mathrm{n}=72$ ) were excluded from the analysis. Specific serum immunoglobulin (Ig)E against a panel of aeroallergens was determined by Fluorescence Enzyme Immuno Assay (SX1 CAP; Pharmacia, Lund, Sweden). SPTs were performed in 1,360 (58.4\%) children aged 5-7 yrs and 2,260 (61.6\%) children aged 9-11 yrs. Blood samples were drawn from 954 $(41.0 \%)$ children in the younger and 2,083 (56.8\%) children in the older age group.

Measurements of lung function were offered only to a random subsample of the 9-11 yr old children $(n=1,999)$. Spirometric measurements (Master Scope 4.1, Jäger, Würzburg, Germany) were performed according to the quality control criteria of the American Thoracic Society $[22,23]$. The FEV1 and the forced expiratory flow over the middle half of the vital capacity (FEF25-75\%) were expressed as a percentage of the predicted values based on sex and height [24]. Bronchial responsiveness was assessed only in children with an FEV1 $>75 \%$ predicted. These children inhaled nebulized hypertonic (4.5\%) saline for periods of increasing duration (0.5, 1, 2, 4, 8 min). After each inhalation period the FEV1 was measured. Children were classified as BHR if the FEV1 had fallen by $\geq 15 \%$ from baseline [25]. One thousand two hundred and fifty-six children $(62.8 \%)$ took part in spirometry. Among these, 140 subjects could not be challenged because of technical or organisational problems, 61 children did not complete the bronchial challenge because of health complaints (e.g. cough, nausea) or limited motivation, and 7 children were not challenged at all because of a baseline FEV1: $\leq 75 \%$ pred. The bronchial challenge was successfully completed by $1,048(52.4 \%)$ children.

Written informed consent was obtained from the parents for each study instrument separately. The study was part of a multicentre project (ISAAC Germany Phase II) and was approved by the ethics committee of the University of Münster.

\section{Air pollution monitoring}

Between April 1994 and April 1995, outdoor air pollution in the populated area of Dresden was monitored in a $1 \times 1 \mathrm{~km}$ grid in the Gauss-Krüger (GK)-coordinate system [26]. For 182 grid-points $0.5 \mathrm{~h}$ mean concentrations of $\mathrm{SO}_{2}$ (ultraviolet fluorescence), $\mathrm{NO}_{2}$ (chemiluminescence), $\mathrm{CO}$ (infrared absorption), and $\mathrm{O}_{3}$ (ultraviolet photometry) were determined $26 \times 4 \mathrm{~m}$ above ground by monitoring stations placed on caravans meeting the standards set by the Federal Ministers of the Interior [27] and Environment [28]. The monitoring stations were placed as close to each GK-gridpoint as possible but never more than $200 \mathrm{~m}$ away from it. The majority of the monitoring sites was situated at small and very small streets in residential districts or field-paths in the surroundings of Dresden representing "city background sites". Twentynine $(15.9 \%)$ of the 182 monitoring stations were situated in streets with dense traffic $\left(>5000\right.$ cars $\left.\cdot 24 \mathrm{~h}^{-1}\right)$. 
The measurements were carried out approximately every fortnight at varying times between $06: 00 \mathrm{~h}$ and $23: 00 \mathrm{~h}(10 \%$ of the measurements on holidays). An equal distribution of times and weekdays was ensured for all sets of 104 measurements at the corners of a $1 \times 1 \mathrm{~km}$ square but was also aspired for the 26 measurements at the single points. Measurement quality was controlled by daily calibration with internal standards (accepted range $\pm 10 \%$ about the reference), and unannounced control measurements with external standards [26]. In addition, at each measurement $50 \mathrm{~L}$ of air were vacuumed separately over activated carbon, and analysed by gas chromatography for benzene (Siemens GC 1/4; Siemens AG, MünchenBerlin, Germany) according to guideline $3482 / 4$ of the "Verein Deutscher Ingenieure". Annual mean immission at a given grid-point was calculated as the arithmetic mean of the 26 values determined at this point.

\section{Estimation of individual exposure}

Home addresses of all children and school addresses of the 9-11 yr olds were assigned to GK-coordinates by means of a geographical information system (SICAD; Siemens/Nixdorf AG. München-Paderborn, Germany; theoretical exactness $0.1 \mathrm{~m}$ ). One hundred and three home addresses not included in this database were located on topographic maps with an accuracy of about $\pm 50 \mathrm{~m}$ and then assigned to GK coordinates. The children's exposure at the home address or the school address was estimated using the annual mean immission values from the nearest monitoring station in each of the four geographical directions (in most cases at the corners of the $1 \times 1 \mathrm{~km}$ square in which the address was located). These four values, weighted by the inverse of the square of their distance to the respective address, were averaged (Stuttgarter Contour Programme (SCOP)) to create, maintain and apply digital terrain models. Institute of Photogrammetry and Remote Sensing, University of Technology, Vienna, Austria, 1994). The 95th percentile of the 104 values measured at these four stations during the year was used as a proxy of the peak exposure of each child. In 168 children living in the periphery of the monitored area, one or two of the four monitoring stations were located $>1 \mathrm{~km}$ from the others. Values from these stations were not used for the assessment of peak exposure. For 9-11 yr old children, a combined estimate was also calculated as the mean of the estimates of exposure at home and at school.

The exposure estimates could be validated against a continuous monitoring station in the city $100 \mathrm{~m}$ from a street with dense traffic $\left(>5000\right.$ cars $\left.24 \mathrm{~h}^{-1}\right)$. The yearly mean concentrations of $\mathrm{SO}_{2}, \mathrm{NO}_{2}$ and $\mathrm{O}_{3}$ measured continuously at this station were compared with estimates based on the noncontinuous measurements at the four nearest gridpoints: $\mathrm{SO}_{2} 42.3 \mu \mathrm{g} \cdot \mathrm{m}^{3}$ (continuous) versus $46.1 \mu \mathrm{g} \cdot \mathrm{m}^{3}$ (noncontinuous); $\mathrm{NO}_{2} 25.5 \mu \mathrm{g} \cdot \mathrm{m}^{3}$ versus 32.1 $\mu \mathrm{g} \cdot \mathrm{m}^{3} ; \mathrm{O}_{3} 44.1$ versus $48.9 \mu \mathrm{g} \cdot \mathrm{m}^{3}$. The values estimated by discontinuous measurements might be slightly higher because no gridpoint measurements were performed between 23:00h and 06:00h at night.

\section{Data analysis}

The analyses were restricted to children with complete addresses who had lived in Dresden for at least 12 months and, because of concerns regarding the validity of questionnaire responses, who had German nationality. This reduced the number of children to 2,796 and 2,625 with completed questionnaires, 1,138 and 2,050 with SPT, as well as 870 and 1,887 with serum IgE measurements in the younger and older age groups, respectively. Measurements of lung function were analysed for 1,137 children aged 911 years. When comparing the questionnaire responders selected for the analyses $(n=5,421)$ with those excluded ( $n$ =936), no significant differences were found with respect to all health outcomes as listed in table 1 . In the selected group, exposure to maternal smoking (26.6 versus $21.4 \%$ ) and lower parental education (72.8 versus $67.1 \%$ ) were more prevalent as compared to the nonselected group. Furthermore, slightly more children of the higher age group were selected (48.5 versus $44.9 \%$ ). No significant differences were found for the other potential confounders included in the multivariate models (see below).

Table 1. - Respiratory health and atopy in the study population

\begin{tabular}{lrr}
\hline & $5-7$ yr olds & $9-11$ yr olds \\
\hline Symptoms in the past 12 months & & \\
Wheeze & $188 / 2730(6.9)$ & $210 / 2595(8.1)$ \\
Morning cough & $279 / 2737(10.2)$ & $310 / 2592(12.0)^{*}$ \\
Symptoms of allergic rhinoconjunctivitis & $153 / 2727(5.6)$ & $325 / 2567(12.7)^{*}$ \\
Symptoms of atopic eczema & $317 / 2737(11.6)$ & $409 / 2588(15.8)^{*}$ \\
Doctor's diagnosis & $158 / 2700(5.9)$ & $203 / 2582(7.9)^{*}$ \\
Asthma & $826 / 2512(32.9)$ & $920 / 2478(37.1)^{*}$ \\
Bronchitis & $\mathrm{ND}$ & $156 / 956(16.3)$ \\
Pulmonary function & $\mathrm{ND}$ & $72 / 1137(6.3)$ \\
Bronchial hyperresponsiveness & $\mathrm{ND}$ & $150 / 1123(13.4)$ \\
FEV1 <85\% pred. & & \\
FEF25-75\% $<70 \%$ pred. & $190 / 870(21.8)$ & $605 / 1887(32.1)^{*}$ \\
Atopy & $146 / 1138(12.8)$ & $534 / 2050(26.0)^{*}$ \\
Specific IgE to aeroallergens $>0.7 \mathrm{kU} \cdot \mathrm{L}^{-1}$ & & \\
SPT reaction $\geq 3$ mm to at least one allergen*** & & \\
\hline
\end{tabular}

Data are presented as absolute numbers, with percentages in parentheses. $*$ : $\mathrm{p}<0.05$ for Chi-squared test for comparison of age groups; **: Fluorescence Enzyme Immuno Assay (SX1 panel; Pharmacia, Lund, Sweden): timothy grass, rye, birch, hazel, Cladosporium herbarum, Dermatophagoides pteronyssinus, cat dog; ***: Skin-prick test solution (ALK, Hörsholm, Denmark): Grass mixture, tree mixture, D. pteronyssinus, D. farinae, cat, Alternaria tenuis. Bronchial hyperresponsiveness was asssessed with $4.5 \% \mathrm{NaCl}$. FEV1: forced expiratory volume in one second; FEF25-75\%: forced mid-expiratory flow; IgE: immunoglobulin E; ND: not done. 
Only 31 children $(0.5 \%)$ were excluded because of foreign nationality.

At first the crude association between pollutant exposure and the health outcomes shown in table 1 was assessed. The crude association between categories of benzene concentrations, a close indicator of traffic emissions, and the health outcome variables was analysed using the MantelHaenszel Chi-squared tests for linear trends. Multivariate logistic regression analyses were performed to assess the effects of the following putative confounding variables: sex, age group, birth weight, parental education, maternal smoking, season of testing, central heating, furry pets, damp housing, carpets, and floor level of the dwelling. Variables were included as potential confounders into the multiple logistic regression model if they were associated with at least one health outcome in the crude analysis (Chi-squared test, $\mathrm{p}<0.25$ ) and changed at least one pollutant's effect estimate by $>20 \%$ when included in the multivariate model. Five variables (sex, age group, birth weight, furry pets, carpets) were included although they failed to change the effect estimates significantly because they were strongly associated with at least one outcome $(\mathrm{p}<0.05)$ and were regarded as potential confounders in comparable studies $[8,14]$. Each covariate in the multivariate model was tested for interaction with the pollutant effects (likelihood ratio test $\mathrm{p}<0.05$ ). The estimated individual air pollutant exposure was treated as continuous linear variable in all logistic regression models. Odds ratios were calculated for concentration differences (approximately interquartile ranges) as they are common in inner cities. The analyses were performed using SPSS for Microsoft Windows 6.01 (SPSS Inc., Chicago, IL, USA).

\section{Results}

The mean \pm SD age of the studied children was $5.3 \pm 0.8$ yrs in the younger age group, and $9.7 \pm 0.6$ yrs in the older age group. Fifty-two per cent were male. The prevalence of atopy and all respiratory symptoms and diagnoses except wheeze was significantly higher in 9-11 yr old children (table 1). The estimated individual exposures to different air pollutants at the home address are given in table 2 . The exposure to $\mathrm{SO}_{2}, \mathrm{NO}_{2}, \mathrm{CO}$ and benzene at school was on average $2.8-3.4 \%$ higher than at home.

A significant increase in the prevalence of morning cough in the past 12 months $(p=0.0007)$ and the lifetime prevalence of doctor diagnosed bronchitis $(\mathrm{p}=0.01)$ across categories of rising benzene exposure $\left(<3 \mu \mathrm{g} \cdot \mathrm{m}^{3}->4.5\right.$ $\mu \mathrm{g} \cdot \mathrm{m}^{3}$ ) was seen (table 3 ). Similar, but less pronounced trends were found for the prevalence of wheeze in the past

Table 2. - Estimated mean annual exposure to air pollutants at home address

\begin{tabular}{lccccc}
\hline & & mean & minimum & $\begin{array}{c}25-75 \\
\text { percentile }\end{array}$ & maximum \\
\hline $\mathrm{SO}_{2}$ & $\mu \mathrm{g} \cdot \mathrm{m}^{3}$ & 48.3 & 29.0 & $42.7-54.3$ & 69.3 \\
$\mathrm{NO}_{2}$ & $\mu \mathrm{g} \cdot \mathrm{m}^{3}$ & 33.8 & 17.1 & $29.3-37.8$ & 56.0 \\
$\mathrm{CO}$ & $\mathrm{mg} \cdot \mathrm{m}^{3}$ & 0.69 & 0.32 & $0.55-0.76$ & 1.54 \\
$\mathrm{Benzene}$ & $\mu \mathrm{g} \cdot \mathrm{m}^{3}$ & 4.0 & 1.9 & $3.3-4.4$ & 8.7 \\
$\mathrm{O}_{3}$ & $\mu \mathrm{g} \cdot \mathrm{m}^{3}$ & 46.0 & 30.3 & $43.1-49.1$ & 64.0 \\
\hline
\end{tabular}

12 months $(\mathrm{p}=0.05)$, the proportion of children with reduced FEF25-75\% values $(p=0.06)$ and a doctor's diagnosis of asthma ( $p=0.15)$. In contrast, no trend was seen for the occurrence of airway hyperresponsiveness or reduced FEV1 values over increasing exposure categories. Furthermore, atopic sensitization as assessed by SPT and specific IgE tended to be inversely associated with rising benzene concentrations.

After adjusting for potential confounding factors morning cough in the past 12 months showed the most consistent positive association with the annual mean exposure to several air pollutants: $\mathrm{SO}_{2}, \mathrm{NO}_{2}, \mathrm{CO}$ and benzene (table 4). For example, the prevalence of morning cough was estimated to increase by $\sim 20 \%$ per increase of $1 \mathrm{mg} \cdot \mathrm{m} 3$ benzene. Likewise, the lifetime prevalence of bronchitis was significantly and positively associated with levels of $\mathrm{NO}_{2}, \mathrm{CO}$ and benzene (but not $\mathrm{SO}_{2}$ ). In contrast, yearly mean ozone exposure tended to be negatively associated with morning cough and bronchitis.

In an attempt to disentangle the specific effect of ozone from that of the other traffic related pollutants $\mathrm{O}_{3}$ was introduced into the multivariate model in combination with other traffic related pollutants. This procedure generally reduced the point estimates of the odds ratios and widened the confidence intervals probably due to colinearity of these strong inversely correlated gases $\left(\mathrm{O}_{3}-\mathrm{NO}_{2}: \mathrm{r}=0.66\right.$, $\mathrm{O}_{3}-\mathrm{CO}: \mathrm{r}=-0.55$, and $\mathrm{O}_{3}$-benzene: $\left.\mathrm{r}=-0.59\right)$. However the general pattern of the observed associations remained unchanged (data not shown).

No clear pattern emerged for the associations between air pollutant exposure and asthmatic conditions. There was a trend towards a positive association between exposure to several pollutants and the lifetime prevalence of doctor diagnosed asthma, but this association reached statistical significance only for the combined estimate of exposure to benzene at home and at school address. No significant association was found between the mean level of air pollution and wheeze in the past 12 months (table 4). Moreover, neither the frequency of wheezing episodes nor the prevalence of speech limiting or sleep disturbing asthma attacks in the past 12 months was significantly associated with exposure to any of the pollutants (data not shown).

BHR was negatively associated with $\mathrm{NO}_{2}$ and $\mathrm{CO}$, and positively associated with $\mathrm{O}_{3}$. No increased risk of atopic sensitization was seen for any pollutant. Likewise, neither a doctor's diagnosis of hay fever and eczema nor symptoms of allergic rhinoconjunctivitis and atopic eczema in the past 12 months were associated with outdoor air pollution exposure (data not shown).

When stratifying children with doctor diagnosed asthma into atopic (SX1 CAP; Pharmacia; $>0.7 \mathrm{kU} \cdot \mathrm{L}^{-1}$ ) and nonatopic asthmatics no significant association was found between pollutant exposure and atopic asthma. Nonatopic asthma, however, was significantly associated with pollutant exposure (except for $\mathrm{O}_{3}$ ). Similar differences were found when comparing the adjusted prevalence odds ratios (aPOR) for morning cough and bronchitis in atopic and nonatopic children. For wheeze the difference was less pronounced (table 5).

The subgroups of children with doctor diagnosed asthma, BHR, or a parental history of atopic diseases were not at a higher risk for adverse health effects of air pollution than the total population (data not shown). Information on 
asthma medication was available for 180 of the 361 asthmatic children. Among these children increasing levels of pollutant exposure were not associated with an increased use of inhaled steroids (data not shown). There was no effect modification by age group.

The associations between 95th percentile pollutant exposures and morning cough or bronchitis were somewhat weaker but still significantly positive for $\mathrm{NO}_{2}$ and benzene when considering the home address (data not shown). In turn, the significant inverse association with. annual mean $\mathrm{O}_{3}$ exposure was not seen for high exposure to $\mathrm{O}_{3}$ (aPOR for morning cough $0.92(0.81-1.05$ ) and bronchitis $1.04(0.65-1.67))$. Current wheeze was marginally positively associated with peak exposure to $\mathrm{NO}_{2}$ (aPOR: 1.16 (1.01-1.33)) and $\mathrm{SO}_{2}$ (aPOR: 1.06 (1.001.12)) at home address but these associations were not found for doctor diagnosed asthma, baseline pulmonary function, or BHR. No significant associations were found between peak pollutant exposure and atopic sensitization.

\section{Discussion}

The results of this survey suggest that moderate increases in inner city air pollution well below the national ambient air quality standards $[29,30]$ are associated with an increased prevalence of morning cough and doctor diagnosed bronchitis, but not of airway hyperresponsiveness, atopic sensitization, or symptoms of atopic diseases in children.

Inner city air pollution has many sources of which car traffic is one important contributor. In Dresden the pollutant measurements presented here have also been related to actual traffic counts. In these estimates $87 \%$ of the total benzene emission was attributable to road traffic [31]. For other pollutants the association with traffic was lower: $46 \%$ of the $\mathrm{NO}_{2}$ emission, $48 \%$ of the $\mathrm{CO}$ emission, and only $1.7 \%$ of the $\mathrm{SO}_{2}$ emission could be ascribed to motor vehicle exhausts [32]. Anthropogenic $\mathrm{O}_{3}$ is produced by photochemical reactions involving $\mathrm{NO}_{2}$. It is reduced in the presence of high NO concentrations which occur in areas with dense traffic. Therefore, the measured $\mathrm{O}_{3}$ levels were inversely correlated with concentrations of $\mathrm{NO}_{2}, \mathrm{CO}$, and benzene.

The adverse health effects were related to exposure to several pollutants. The prevalence of morning cough and bronchitis was positively associated with exposure to benzene, $\mathrm{NO}_{2}$ and $\mathrm{CO}$, and inversely related to $\mathrm{O}_{3}$. Benzene concentrations are almost exclusively attributable to motor vehicle emissions. Concentrations of $\mathrm{NO}_{2}$ and $\mathrm{CO}$ are also determined to a substantial degree by traffic but also by other sources (e.g. indoor heating and industrial combustion). Thus, traffic is an important but not the only source of agents which may account for the observed associations.

$\mathrm{SO}_{2}$ was positively associated with current morning cough but not with bronchitis. This pollutant predominantly represents other sources than traffic therefore its longterm effects may differ from those of the other pollutants. The inverse associations of annual mean $\mathrm{O}_{3}$ exposure with morning cough and bronchitis were not seen for peak exposures to $\mathrm{O}_{3}$. Exposure to high concentrations of $\mathrm{O}_{3}$ are known to induce airway irritation [33] and impairment of pulmonary function [34]. This may counteract the inverse effects of low traffic exposure in some districts of the Dresden area.

There was no positive association between exposure to benzene, $\mathrm{NO}_{2}$ and $\mathrm{CO}$ and the prevalence of symptoms or diagnoses of hay fever and eczema, atopic sensitization, and BHR. The associations between pollutant exposure and respiratory symptoms and diagnoses were clearly stronger in nonatopic than in atopic children. These findings are in line with the hypothesis that these air pollutants induce nonspecific irritative rather than allergic inflammatory changes in the airway mucosa, Irritative effects would affect the clinical course in nonatopic children more

Table 3. - Prevalence of respiratory symptoms and diseases, reduced pulmonary function, and atopy in all children* by categories of exposure to benzene

\begin{tabular}{|c|c|c|c|c|c|c|}
\hline & \multicolumn{6}{|c|}{ Estimated outdoor exposure to benzene at home address** } \\
\hline & $-3 \mu \mathrm{g} \cdot \mathrm{m}^{3}$ & $-3.5 \mu \mathrm{g} \cdot \mathrm{m}^{3}$ & $-4 \mu \mathrm{g} \cdot \mathrm{m}^{3}$ & $-4.5 \mu \mathrm{g} \cdot \mathrm{m}^{3}$ & $>4.5 \mu \mathrm{g} \cdot \mathrm{m}^{3}$ & p-value $* * *$ \\
\hline \multicolumn{7}{|l|}{ Symptoms in the past 12 months } \\
\hline Wheeze & $37 / 660(5.6)$ & $72 / 1035(7.0)$ & $80 / 1079(7.4)$ & $117 / 1334(8.8)$ & 92/1217 (7.6) & 0.054 \\
\hline Morning cough & $58 / 657(8.8)$ & $92 / 1036(8.9)$ & $120 / 1089(11.0)$ & $171 / 1334(12.8)$ & $148 / 1213(12.2)$ & 0.00073 \\
\hline \multicolumn{7}{|l|}{ Doctor's diagnosis } \\
\hline Asthma & $32 / 643(5.0)$ & $71 / 1022(6.9)$ & $74 / 1081(6.8)$ & $99 / 1316(7.5)$ & $85 / 1220(7.0)$ & 0.15 \\
\hline Bronchitis & 205/612 (33.5) & $316 / 975(32.4)$ & $348 / 1007$ (34.6) & $444 / 1251(35.5)$ & $433 / 1145(37.8)$ & 0.011 \\
\hline \multicolumn{7}{|l|}{ Pulmonary function } \\
\hline Bronchial hyperresponsiveness & 14/77 (18.2) & $33 / 149(22.1)$ & $30 / 226(13.3)$ & $47 / 290(16.2)$ & $32 / 214(15.0)$ & 0.20 \\
\hline FEV $1<85 \%$ pred. & $5 / 118(4.2)$ & $13 / 201(6.5)$ & $15 / 251(6.0)$ & $26 / 334(7.8)$ & $13 / 233(5.6)$ & 0.56 \\
\hline FEF $25-75 \%<70 \%$ pred. & $9 / 117(7.7)$ & $25 / 198(12.6)$ & $31 / 248(12.5)$ & $52 / 327(15.9)$ & $33 / 233(14.2)$ & 0.064 \\
\hline \multicolumn{7}{|l|}{ Atopy } \\
\hline $\begin{array}{l}\text { Specific } \operatorname{IgE} \text { to aeroallergens } \\
>0.7 \mathrm{kU} \cdot \mathrm{L}^{-1}\end{array}$ & $109 / 317(34.4)$ & $137 / 526(26.0)$ & $191 / 611(31.3)$ & 206/692 (29.8) & $152 / 611(24.9)$ & 0.045 \\
\hline $\begin{array}{l}\text { SPT reaction } \geq 3 \mathrm{~mm} \text { to at } \\
\text { least one allergen }\end{array}$ & $87 / 372(23.4)$ & $123 / 609(20.2)$ & $169 / 681(24.8)$ & $172 / 816(21.1)$ & $129 / 710(18.2)$ & 0.069 \\
\hline
\end{tabular}

*: The results are presented for 5-7 and 9-11 yr olds combined, with percentages in parentheses. **: categories of benzene exposure are characterized by their upper limits except for the highest category. The extreme categories represent larger ranges of exposure in order to achieve sufficiently large sample sizes; ***: Mantel-Haenszel Chi-Square test for linear trend. Bronchial hyperresponsiveness was assessed with 4.5\% NAC. FEV1: forced expiratory volume in one second; FEF25-75\%: forced mid-expiratory flow; IgE: immunoglobulin E. 
Table 4. - Association of respiratory symptoms and diseases, pulmonary function, and atopy in children with exposure to inner city air pollutants at home (EHA) and at home and school sddress (EHSA)

\begin{tabular}{|c|c|c|c|c|c|c|}
\hline & $\begin{array}{l}\text { Subjects } \\
\mathrm{n}^{*}\end{array}$ & $\begin{array}{l}\mathrm{SO}_{2} \\
+10 \mu \mathrm{g} \cdot \mathrm{m}^{3}\end{array}$ & $\begin{array}{c}\mathrm{NO}_{2} \\
+10 \mu \mathrm{g} \cdot \mathrm{m}^{3}\end{array}$ & $\begin{array}{c}\mathrm{CO} \\
+0.2 \mu \mathrm{g} \cdot \mathrm{m}^{3}\end{array}$ & $\begin{array}{l}\text { Benzene } \\
+1 \mu \mathrm{g} \cdot \mathrm{m}^{3}\end{array}$ & $\begin{array}{c}\mathrm{O}_{3} \\
+10 \mu \mathrm{g} \cdot \mathrm{m}^{3}\end{array}$ \\
\hline \multicolumn{7}{|c|}{$\begin{array}{l}\text { Symptoms in the } \\
\text { past } 12 \text { months }\end{array}$} \\
\hline \multicolumn{7}{|c|}{ Wheeze } \\
\hline EHA & 4518 & $1.07(0.92-1.24)$ & $1.13(0.93-1.37)$ & $1.05(0.93-1.18)$ & $1.05(0.93-1.18)$ & $0.84(0.66-1.07)$ \\
\hline EHSA & 2218 & $1.09(0.86-1.38)$ & $0.95(0.72-1.26)$ & $1.02(0.85-1.22)$ & $1.08(0.90-1.29)$ & $0.79(0.56-1.13)$ \\
\hline \multicolumn{7}{|c|}{ Morning cough } \\
\hline EHA & 4515 & $1.16(1.02-1.31)$ & $1.22(1.04-1.44)$ & $1.12(1.01-1.23)$ & $1.15(1.04-1.27)$ & $0.80(0.65-0.98)$ \\
\hline EHSA & 2211 & $1.30(1.06-1.59)$ & $1.21(0.96-1.52)$ & $1.13(0.98-1.30)$ & $1.21(1.04-1.40)$ & $0.71(0.53-0.96)$ \\
\hline \multicolumn{7}{|c|}{ Doctor's diagnosis } \\
\hline \multicolumn{7}{|c|}{ Asthma } \\
\hline EHA & 4477 & $1.06(0.90-1.24)$ & $1.16(0.94-1.42)$ & $1.07(0.94-1.21)$ & $1.11(0.97-1.25)$ & $0.79(0.61-1.02)$ \\
\hline EHSA & 2203 & $1.05(0.83-1.34)$ & $1.14(0.86-1.51)$ & $1.16(0.97-1.38)$ & $1.21(1.01-1.45)$ & $0.62(0.43-0.89)$ \\
\hline \multicolumn{7}{|c|}{ Bronchitis } \\
\hline EHA & 4228 & $0.92(0.85-1.00)$ & $1.23(1.11-1.38)$ & $1.19(1.11-1.27)$ & $1.11(1.03-1.19)$ & $0.83(0.73-0.96)$ \\
\hline EHSA & 2114 & $0.91(0.80-1.04)$ & $1.27(1.09-1.49)$ & $1.24(1.12-1.38)$ & $1.16(1.04-1.29)$ & $0.83(0.67-1.02)$ \\
\hline \multicolumn{7}{|c|}{ Pulmonary function } \\
\hline \multicolumn{7}{|c|}{$\mathrm{BHR}$} \\
\hline EHA & 838 & $0.92(0.68-1.23)$ & $0.61(0.45-0.84)$ & $0.79(0.63-0.99)$ & $0.80(0.62-1.03)$ & $1.52(1.00-2.31)$ \\
\hline EHSA & 838 & $0.94(0.66-1.34)$ & $0.58(0.41-0.82)$ & $0.77(0.60-0.99)$ & $0.81(0.62-1.06)$ & $1.60(1.02-2.52)$ \\
\hline \multicolumn{7}{|c|}{ FEV $1<85 \%$ pred. } \\
\hline EHA & 992 & $1.24(0.83-1.83)$ & $0.95(0.62-1.44)$ & $1.09(0.81-1.47)$ & $1.19(0.86-1.64)$ & $1.20(0.70-2.07)$ \\
\hline EHSA & 992 & $1.44(0.89-2.33)$ & $0.85(0.54-1.36)$ & $1.01(0.73-1.41)$ & $1.17(0.81-1.67)$ & $1.34(0.76-2.37)$ \\
\hline \multicolumn{7}{|c|}{ FEF $25-75 \%<70 \%$ pred. } \\
\hline EHA & 981 & $1.18(0.90-1.56)$ & $1.14(0.86-1.51)$ & $1.15(0.94-1.39)$ & $1.27(1.03-1.58)$ & $0.75(0.51-1.10)$ \\
\hline EHSA & 981 & $1.25(0.90-1.73)$ & $1.05(0.78-1.43)$ & $1.07(0.86-1.34)$ & $1.17(0.92-1.50)$ & $0.89(0.59-1.32)$ \\
\hline \multicolumn{7}{|c|}{ Atopy } \\
\hline \multicolumn{7}{|c|}{$\begin{array}{l}\text { Specific IgE against aero- } \\
\text { allergens }>0.7 \mathrm{kU} \cdot \mathrm{L}^{-1}\end{array}$} \\
\hline EHA & 2361 & $1.02(0.90-1.16)$ & $0.96(0.82-1.12)$ & $0.95(0.86-1.06)$ & $0.98(0.88-1.09)$ & $0.93(0.76-1.13)$ \\
\hline EHSA & 1629 & $0.87(0.74-1.03)$ & $0.89(0.73-1.08)$ & $0.94(0.83-1.06)$ & $0.92(0.81-1.05)$ & $1.06(0.82-1.35)$ \\
\hline \multicolumn{7}{|c|}{$\begin{array}{l}\text { SPT reaction } \geq 3 \mathrm{~mm} \text { to } \\
\text { at least one allergen }\end{array}$} \\
\hline EHA & 2729 & $1.03(0.90-1.17)$ & $1.01(0.86-1.19)$ & $0.99(0.89-1.10)$ & $1.02(0.92-1.14)$ & $0.94(0.76-1.16)$ \\
\hline EHSA & 1760 & $0.92(0.78-1.08)$ & $1.02(0.84-1.24)$ & $1.01(0.90-1.15)$ & $1.01(0.89-1.15)$ & $0.98(0.76-1.26)$ \\
\hline
\end{tabular}

Data are presented as absolute numbers (subjects) or prevalence odds ratio (POR) with $95 \%$ confidence intervals $(95 \% \mathrm{CI}$ ) in parentheses $\left(\mathrm{SO}_{2}, \mathrm{NO}_{2}, \mathrm{CO}\right.$, benzene and $\left.\mathrm{O}_{3}\right)$. POR and 95\% CI were calculated by logistic regression analysis adjusting for the following putative confounding variables: sex, age group, birth weight, parental education, maternal smoking, season of testing, central heating, furry pets, damp housing, carpets, and floor level. Exposure at home address (EHA) was estimated for 5-7 and 9-11 yr olds combined. Exposure at home and school address (EHSA) was estimated for 9-11 yr olds only as the mean of exposures determined for home and school address. BHR: bronchial hyperresponsiveness; FEV1: forced expiratory volume in one second; FEF25-75\%: forced mid-expiratory flow; IgE: immunoglobulin E; SPT: skin-prick test.

strongly than in atopics whose symptoms are also determined by allergen exposure.

The observation that the level of exposure was associated with nonatopic asthma and not with atopic asthma corroborates this notion. In this nonatopic subgroup, asthma may mainly be triggered or induced by viral infections. Some evidence suggests that the development of childhood respiratory tract infections is in fact related to increasing exposure to $\mathrm{SO}_{2}, \mathrm{NO}_{2}$ and particles $[3,4,15]$. Alternatively, irritative symptoms due to higher pollution exposure may result in more frequent visits to a physician who may then be more likely to misclassify a bronchitic child as asthmatic. In this case the association of pollutant exposure with asthma would have been overestimated and the association with bronchitis would have been underestimated in this study.

The selection of children with German nationality who had lived for $\geq 12$ months in Dresden resulted in a population with slightly higher exposure to maternal smok- ing and lower parental education. In such children outdoor pollution may contribute to a smaller amount to the overall effects of environmental hazards. Therefore the associations between outdoor pollution and respiratory health or atopy might have been underestimated in this study. The reduction of the study population by selection of children with German nationality was quantitatively negligible. In addition, ethnicity has been shown to be a significant determinant for the prevalence of atopic diseases in Germany [35].

When interpreting these findings it is important to bear in mind that in Dresden, as in many other areas of the former East Germany, exposure to air pollution has changed tremendously in the first years after German reunification in 1989. Levels of $\mathrm{SO}_{2}$ have decreased substantially between 1989-1992 [36] and car traffic exposure has increased between 1990-1994 [37]. The adverse health effects seen in this study are therefore likely to reflect exposure in the past few years. The exposure 
Table 5. - Association of respiratory symptoms and diseases with exposure to inner city air pollutants at home address ${ }^{*}$ in atopic and nonatopic children

\begin{tabular}{|c|c|c|c|c|c|c|}
\hline & $\begin{array}{c}\text { Subjects } \\
\mathrm{n}\end{array}$ & $\begin{array}{c}\mathrm{SO}_{2} \\
+10 \mu \mathrm{g} \cdot \mathrm{m}^{3}\end{array}$ & $\begin{array}{c}\mathrm{NO}_{2} \\
+10 \mu \mathrm{g} \cdot \mathrm{m}^{3}\end{array}$ & $\begin{array}{c}\mathrm{CO} \\
+0.2 \mu \mathrm{g} \cdot \mathrm{m}^{3}\end{array}$ & $\begin{array}{l}\text { Benzene } \\
+1 \mu \mathrm{g} \cdot \mathrm{m}^{3}\end{array}$ & $\begin{array}{c}\mathrm{O}_{3} \\
+10 \mu \mathrm{g} \cdot \mathrm{m}^{3}\end{array}$ \\
\hline \multirow{2}{*}{\multicolumn{7}{|c|}{$\begin{array}{l}\text { Symptoms in the past } \\
12 \text { months** } \\
\text { Wheeze }\end{array}$}} \\
\hline & & & & & & \\
\hline Atopic children $^{+}$ & 4391 & $1.03(0.79-1.35)$ & $1.05(0.76-1.45)$ & $1.00(0.81-1.24)$ & $1.02(0.83-1.27)$ & $0.81(0.53-1.23)$ \\
\hline Nonatopic children & 4379 & $1.36(1.01-1.84)$ & $1.16(0.79-1.70)$ & $1.05(0.83-1.31)$ & $1.09(0.87-1.36)$ & $1.08(0.68-1.73)$ \\
\hline \multicolumn{7}{|l|}{ Morning cough } \\
\hline Atopic children $^{+}$ & 4316 & $1.22(0.92-1.61)$ & $1.09(0.77-1.54)$ & $1.03(0.82-1.29)$ & $1.08(0.86-1.35)$ & $0.67(0.43-1.04)$ \\
\hline Nonatopic children & 4306 & $1.32(1.07-1.63)$ & $1.42(1.10-1.84)$ & $1.22(1.05-1.41)$ & $1.26(1.08-1.46)$ & $0.84(0.60-1.16)$ \\
\hline \multirow{2}{*}{\multicolumn{7}{|c|}{ Doctor's diagnosis }} \\
\hline \multicolumn{4}{|l|}{ Asthma } & & & \\
\hline Atopic children $^{+}$ & 4378 & $1.07(0.79-1.45)$ & $1.01(0.70-1.46)$ & $1.05(0.83-1.32)$ & $1.11(0.88-1.40)$ & $0.88(0.54-1.41)$ \\
\hline Nonatopic children & 4350 & $1.35(1.00-1.82)$ & $1.49(1.04-2.16)$ & $1.29(1.05-1.59)$ & $1.32(1.07-1.62)$ & $0.64(0.40-1.03)$ \\
\hline \multicolumn{7}{|l|}{ Bronchitis } \\
\hline Atopic children $^{+}$ & 3634 & $1.04(0.87-1.25)$ & $1.00(0.79-1.26)$ & $1.00(0.86-1.16)$ & $0.95(0.80-1.11)$ & $1.07(0.80-1.44)$ \\
\hline Nonatopic children & 3585 & $0.99(0.88-1.12)$ & $1.37(1.17-1.62)$ & $1.21(1.10-1.33)$ & $1.13(1.03-1.25)$ & $0.83(0.68-1.01)$ \\
\hline
\end{tabular}

*: Exposure at home address was estimated for 5-7 and 9-11 yr olds combined; **: prevalence odds ratio (POR) and 95\% confidence intervals (in parentheses) were calculated comparing atopic and nonatopic children with specified symptoms or diagnoses with the remaining population not meeting the criteria. The numbers of cases with information on symptoms or diagnoses differed in atopic and nonatopic children. Therefore differnt numbers of cases were included in the models. POR were calculated by logistic regression analysis adjusting for the following putative confounding variables; sex, age group, birth weight, parental education, maternal smoking, season of testing, central heating, furry pets, damp housing, carpets, and floor level; ${ }^{+}$: specific immunoglobulin (Ig)E to aeroallergens $>0.7 \mathrm{kU} \cdot \mathrm{L}^{-1} ;{ }^{\#}$ : specific IgE to aeroallergens $\leq 0.7 \mathrm{kU} \cdot \mathrm{L}^{-1}$.

assessment preceded the measurement of health outcomes by $\sim 1$ yr. There were, however, no major changes in the immission of traffic related air pollutants in Dresden between 1994/95-1995/96 [36] and the questionnaire referred to symptoms in the preceding 12 months.

At the 29 monitoring stations in streets the $\mathrm{NO}_{2}$ concentrations were significantly higher (mean $37.4 \mu \mathrm{g} \cdot \mathrm{m}^{3}$ ) than at the next monitoring sites in eastern $\left(30.3 \mu \mathrm{g} \cdot \mathrm{m}^{3}\right)$, western $\left(32.5 \mu \mathrm{g} \cdot \mathrm{m}^{3}\right)$, northern $\left(30.4 \mu \mathrm{g} \cdot \mathrm{m}^{3}\right)$, or southern $\left(34.3 \mu \mathrm{g} \cdot \mathrm{m}^{3}\right)$ direction (Wilcoxon matched-pairs signedrank Test, each $\mathrm{p}<0.05)$. The measurements of the street monitors may result in an overestimation of exposure for some children living at a short distance from these monitors but not directly in the street where the measurement was done. In contrast, $17.5 \%$ of the children $(948 / 5,421)$ lived in streets with dense traffic $\left(>5000\right.$ cars. $\left.24 \mathrm{~h}^{-1}\right)$. For these children exposure may have been underestimated if none of the four monitoring sites used to estimate their exposure were placed in the street of residence. These types of misclassification of exposure may have lead to an attenuation of the effect estimates.

The exposure estimate does not take building structures around streets into account, but covariates like "floor level of the dwelling" or "window of the child's room opening to a street" did not change the effect estimates significantly. Stratification by parental-reported traffic exposure did not eliminate the associations between pollutant exposure and reported cough or bronchitis. Thus, it is unlikely that preferential reporting of symptoms or diagnoses has distorted the findings.

Other studies have suggested that exposure to truck traffic and black smoke may be associated with asthma symptoms and reduced pulmonary function in children [11-15]. This specific association was not investigated in the current study, because black smoke had not been measured in the $1 \mathrm{~km}^{2}$ grid. In studies which measured both, gases and particles, a close correlation was found between concentrations of $\mathrm{NO}_{2}$ and particulate matter $<10 \mu \mathrm{m}$ in diameter $(\mathrm{PM} 10)(\mathrm{r}=0.94,[8])$, or $\mathrm{NO}_{2}$ and black smoke $(r>0.70,[14])$. However, PM10 does not specifically represent diesel exhausts, and the black smoke concentrations were monitored in schools close to motorways where large variations in traffic density can increase correlations between all traffic dependent pollutants regardless of the specific source. Therefore, the current $\mathrm{NO}_{2}$ exposure estimates cannot be regarded as specific markers of truck traffic exposure.

When including parental reports of truck traffic in the street of residence instead of the estimates of air pollutant exposure into the multivariate model significant associations with morning cough (aPOR for "constant" compared to "no truck traffic": $1.60(1.06-2.42))$ and wheeze (aPOR: 2.09 (1.24-3.53)) were found. Only nonsignificant tendencies towards higher prevalences with increasing traffic exposure were found for both doctor diagnosed asthma and bronchitis, and no association was observed with pulmonary function, BHR, and atopy. This is fairly consistent with the data from two other studies. The first study [11] presented data for chronic cough and found a similar association of this rather unspecific symptom with truck traffic and black smoke exposure as with wheeze. The second study [15] found an association of truck traffic exposure with current wheeze, cough and persistent phlegm, but not with current asthma and not with wheezing episodes in the first two years of life. These authors concluded that air pollution from truck traffic increases the risk for a wide range of adverse respiratory effects but may have a more important role in respiratory infections than in the aetiology of asthma. None of the studies on truck traffic exposure measured bronchial hyperresponsiveness or objective markers of atopy.

The results are also consistent with the findings of DOCKERY et al. [2] and BRAUN-FAHRLÄNDER et al. [8] who showed a significant association between cough and 
bronchitis, but not asthma or atopic conditions with concentrations of particulate matter [2, 8], $\mathrm{NO}_{2}$ and $\mathrm{SO}_{2}$. [8]. Likewise, in children living in Munich, West Germany, high rates of road traffic increased respiratory symptoms, but were not associated with the prevalence of hay fever, asthma, and BHR [9].

In summary, the findings suggest that in children exposure to the traffic related air pollutants $\mathrm{NO}_{2}, \mathrm{CO}$, and benzene is associated with an increased prevalence of cough and bronchitis but not with the prevalence of atopic sensitization, symptoms of atopic diseases, and bronchial hyperresponsiveness.

\begin{abstract}
Acknowledgements. The authors thank J. Jacob from the Saxony State Agency for Environment and Geology for providing detailed background information on the exposure data. The authors thank P. Gebert and his colleagues from the community health department in Dresden and I. Katschner and the teachers of all of the participating schools for their commitment and cooperation. The authors also thank all of the children and parents for their participation.
\end{abstract}

\section{References}

1. Ware JH, Ferris BG, Dockery DW, Spengler JD, Stram DO, Speizer FE. Effects of ambient sulfur oxides and suspended particles on respiratory health of preadolescent children. Am Rev Respir Dis 1986; 133: 834-842.

2. Dockery DW, Speizer FE, Stram DO, Ware JH, Spengler JD, Ferris BG. Effects of inhaled particles on respiratory health of children. Am Rev Respir Dis 1989; 139: 587594.

3. Braun-Fahrländer C, Ackermann-Liebrich U, Schwartz J, Gnehm HP, Rutishauser M, Wanner HU. Air pollution and respiratory symptoms in preschool children. Am Rev Respir Dis 1992; 145: 42-47.

4. von Mutius E, Sherrill DL, Fritzsch C, Martinez F, Lebowitz MD. Air pollution and upper respiratory symptoms in children from East Germany. Eur Respir J 1995; 8: 723-728.

5. Schmitzberger R, Rhomberg K, Büchele H, et al. Effects of air pollution on the respiratory tract of children. Pediatr Pulmonol 1993; 15: 68-74.

6. Studnicka M, Hackl E, Pischinger J, et al. Traffic-related $\mathrm{NO}_{2}$ and the prevalence of asthma and respiratory symptoms in seven year olds. Eur Respir J 1997; 10: 22752278.

7. Corbo GM, Forastiere F, Dell'Orco V, et al. Effects of environment on atopic status and respiratory disorders in children. J Allergy Clin Immunol 1993; 92: 616-623.

8. Braun-Fahrländer C, Vuille JC, Sennhauser FH, et al. Respiratory health and long-term exposure to air pollutants in Swiss schoolchildren. Am J Respir Crit Care Med 1997; 155: 1042-1049.

9. Wjst M, Reitmeir P, Dold S, et al. Road traffic and adverse effects on respiratory health in children. $B M J$ 1993; 307: 596-600.

10. Oosterlee A, Drijver M, Lebret E, Brunekreef B. Chronic respiratory symptoms in children and adults living along streets with high traffic density. Occup Environ Med 1996; 53: 241-247.

11. van Vliet $\mathrm{P}$, Knape $\mathrm{M}$, de Hartog J, Janssen NAH,
Harssema H, Brunekreef B. Motor vehicle exhaust and chronic respiratory symptoms in children living near freeways. Environ Res 1997; 74: 122-132.

12. Weiland SK, Mundt KA, Rückmann A, Keil U. Selfreported wheezing and allergic rhinitis in children and traffic density on street of residence. Ann Epidemiol 1994; 4: 243-247.

13. Duhme H, Weiland SK, Keil U, et al. The association between self-reported symptoms of asthma and allergic rhinitis and self-reported traffic density on street of residence in adolescents. Epidemiology 1996; 7: 578-582.

14. Brunekreef B, Janssen NAH, de Hartog J, Harssema H, Knape M, van Vliet P. Air pollution from truck traffic and lung function in children living near motorways. Epidemiology 1997; 8: 298-303.

15. Ciccone G, Forastiere F, Agabiti N, et al. Road traffic and adverse respiratory effects in children. Occup Environ Med 1998; 55: 771-778.

16. Salvi SS, Frew A, Holgate S. Is diesel exhaust a cause for increasing allergies? Clin Exp Allergy 1999; 29: 4-8.

17. Monn C, Carabias V, Junker M, Waeber R, Karrer M, Wanner HU. Small-scale spatial variability of particulate matter $<10 \mathrm{~mm}(\mathrm{PM} 10)$ and nitrogen dioxide. Atmospheric Environment 1997; 31: 2243-2247.

18. ISAAC Steering Committee. Phase II Modules of the International Study of Asthma and Allergies in Childhood (ISAAC). Münster, 1998.

19. Asher MI, Keil U, Anderson HR, et al. International Study of Asthma and Allergies-ISAAC: rationale and methods. Eur Respir J 1995; 8: 483-491.

20. Medical Research Council, Committee on the Aetiology of Chronic Bronchitis. Standardized questionnaire on respiratory symptoms. Br Med $J$ 1960; 2: 1665.

21. Nicolai T, von Mutius E, Reitmeir P, Wjst M. Reactivity to cold-air hyperventilation in normal and in asthmatic children in a survey of 5,697 schoolchildren in Southern Bavaria. Am Rev Respir Dis 1993; 147: 565-572.

22. Ferris BG. Epidemiology standardization project III: recommended standardized procedures for pulmonary function testing. Am Rev Respir Dis 1978; 118 (6, Part 2): $55-88$.

23. Gardner RM, Hankinson JL, Clausen JL, Crapo RO, Johnson RL, Epler GR. Standardization of spirometry: 1987 update. Official statement of the American Thoracic Society. Am Rev Respir Dis 1987; 136: 1285-1298.

24. Zapletal A, Paul F, Samanek M. Die Bedeutung heutiger Methoden der Lungenfunktionsdiagnostik zur Feststellung einer Obstruktion der Atemwege bei Kindern und Jugendlichen. Z Erkrank Atm Org 1977; 149: 343-371.

25. Riedler J, Reade T, Dalton M, Holst D, Robertson C. Hypertonic saline challenge in an epidemiologic survey of asthma in children. Am J Respir Crit Care Med 1994; 150: 1632-1639.

26. Gesellschaft für Umweltmessungen und Umwelterhebungen mbH, Karlsruhe. Bericht Nr. 31-7/95. Immissionsmessungen im oberen Elbtal. September 1995.

27. Rundschreiben des Bundesministers des Inneren vom 19.8.81 -W18-556 134/4. Bundeseinheitliche Praxis bei der Überwachung der Immissionen. Richtlinien für die Bauausführung und Eignungsprüfung von Meßeinrichtungen zur kontinuierlichen Überwachung der Immissionen. Gemeinsames Ministerialblatt 1981; 32: 335-357.

28. Rundschreffien des Bundesministers für Umwelt vom 9.2.88. Bundeseinheitliche Praxis bei der oberwachung der Immissionen. Richtlinien über die Festlegung von Referenzverfahren, die Auswahlvon Äquivalenzmeßverfahren 
und die Anwendung von Kalibrierverfahren. Gemeinsames Ministerialblatt 1988; 39: 191-195.

29. Erste Allgemeine Verwaltungsvorschrift zum BundesImmissionsschutzgesetz (Technische Anleitung zur Reinhaltung der Luft - TA Luft) vorn 27.2.1986. Gemeinsames Ministerialblatt 1986; 37: 95, 202.

30. 23. Verordnung zur Durchführung des Bundesimmissionschutzgesetzes (Verordnung über die Festlegung von Konzentrationswerten - 23. BImSchV) vom 16.12.1996. Bundesgesetzblatt 1996, Teil 1: 1962-1965.

31. Institut für Troposphärenforschung e.V., Leipzig. Forschungsbericht"Aufnahme derErgebnisse derOzonmodellierung in Dresden und Entwicklung eines hochaufgelösten Katasters (insbesondere Kohlenwasserstoffe) für den Freistaat Sachsen und die entsprechende Modellierung mit Hilfe des mesoskaligen Ausbreitungsmodells METRAS". Auftraggeber: Sächsisches Landesamt für Umwelt und Geologie, Radebeul 1998.

32. Gesellschaft für Umweltmessungen und Umwelterhebungen mbH, Karlsruhe. Bericht Nr. 12-3/96. Emissionen und Immissionen im oberen Elbtal 1994: 62. Karlsruhe, Oktober 1996.

33. Frischer TM, Kuehr J, Pullwit A, et al. Ambient ozone causes upper airways inflammation in children. Am Rev Respir Dis 1993; 148: 961-964.

34. Hoek G, Fischer P, Brunekref B, Lebret E, Hofschreuder $\mathrm{P}$, Mennen MG. Acute effects of ambient ozone on pulmonary function of children in the Netherlands. $\mathrm{Am}$ Rev Respir Dis 1993; 147: 111-117.

35. Kabesch M, Schaal W, Nicolai T, von Mutius E. Lower prevalence of asthma and atopy in Turkish children living in Germany. Eur Respir J 1999; 13: 577-582.

36. Sächsisches Landesamt für Umwelt und Geologic (LfUG). Jahresberichte zur Immissionsssituation 19911996. Sachsisches Landesaint fdr Urnwelt und Geologic, Radebeul 1992-1997.

37. Rechtsamtder Landeshauptstadt Dresden (Abteilung Statistik und Wahlen). Statistische Informationen "Dresden in Zahlen" 1993-1995. Landeshauptstadt Dresden 19941996. 